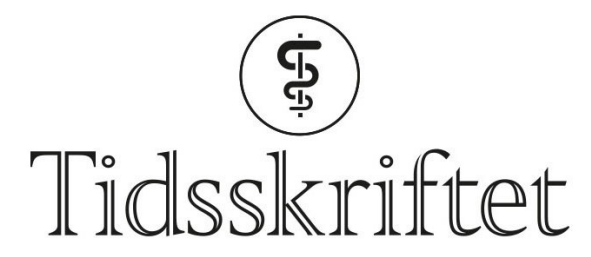

DEN NORSKE LEGEFORENING

\title{
Store forskjeller i dødelighet ved hjertesvikt
}

FRA ANDRE TIDSSKRIFTER

MATILDE RISOPATRON BERG

Sykehuset Innlandet, Hamar

Det er store forskjeller i hjertesviktdødelighet i de ulike verdensdelene.

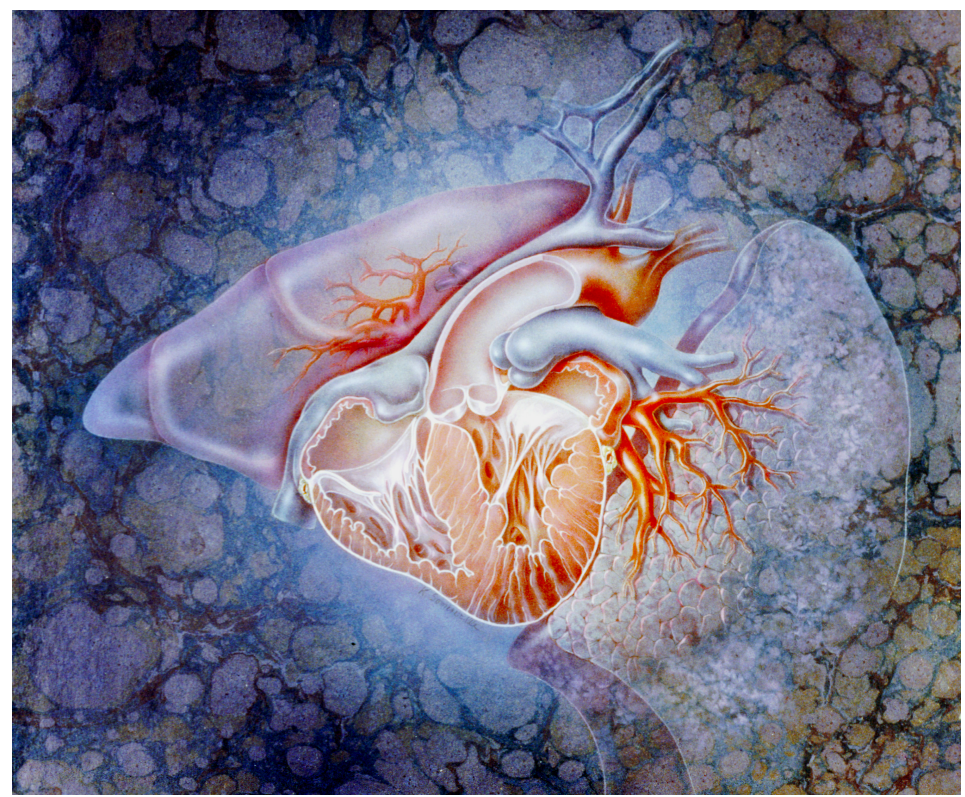

Foto: Science Photo Library

Hjertesvikt er en sykdom med høy dødelighet og store samfunnsmessige kostnader. I en prospektiv kohortstudie er dødelighet hos hjertesviktpasienter unders $\varnothing \mathrm{kt} \mathrm{i} 16$ lavinntektsog mellominntektsland i Afrika, Asia, Sør-Amerika og Midtøsten (1).

Studien omfattet nesten 5700 pasienter med hjertesvikt (gjennomsnittsalder 59 år) fra 108 poliklinikker. Ved ultralydundersøkelse av hjertet hadde nesten halvparten av dem en ejeksjonsfraksjon på under $40 \%$. De vanligste årsakene til hjertesvikt var iskemisk hjertesykdom (39\%), hypertensjon (17\%), kardiomyopati (12\%) og primær hjerteklaffsykdom (11\%).

Etter ett års observasjon var $33 \%$ av pasientene i Afrika og $23 \%$ av pasientene i India døde. I Kina, Sør-Amerika og Midtøsten var kun mellom $7 \%$ og $10 \%$ av pasientene døde etter ett år. Hjertesykdom var årsaken til omtrent halvparten av alle dødsfall hos studiedeltagerne i de fleste landene. Uavhengige risikofaktorer for død var alder, systolisk blodtrykk, 
kroppsmasseindeks, kronisk nyresykdom, kols, langtkommet hjertesvikt, innleggelse i sykehus som følge av hjertesvikt siste år og klaffesykdom bekreftet ved ultralydundersøkelse. Hele $46 \%$ av forskjellene i dødelighet ble forklart ved å justere for disse faktorene. Bosted i Afrika, India eller Sørøst-Asia ga en relativ risiko for død på henholdsvis 3,8, 2,9 og 2,6 sammenlignet med Sør-Amerika.

Forfatterne konkluderer med at de store forskjellene i dødelighet mellom regionene kan skyldes ulikhet i helsetjenester samt i genetiske og miljømessige forhold.

\section{LITTERATUR:}

1. Dokainish H, Teo K, Zhu J et al. Global mortality variations in patients with heart failure: results from the International Congestive Heart Failure (INTER-CHF) prospective cohort study. Lancet Glob Health 2017. E-publisert 3.5.

Publisert: 26. juni 2017. Tidsskr Nor Legeforen. DOI:10.4045/tidsskr.17.0423

(C) Tidsskrift for Den norske legeforening 2020. Lastet ned fra tidsskriftet.no 